\title{
The Effect of Budgeting Process on Organizational Effectiveness: A Case Study in Hadiya Zone Selected Government Finance Organization
}

\author{
Berhanu Dikasso Genkamo* \\ Department of Accounting and Finance, Jimma University, Jimma, Ethiopia \\ Abraham Tessema Handalo(Co-Author) \\ Department of Economics, Jimma University, Jimma, Ethiopia
}

\begin{abstract}
Background: The budgeting process is increasingly recognized as the key tool for organizational effectiveness. It is nevertheless also recognized that a country can have a sound budget and financial system and still fail to achieve its intended targets. This suggests that the rules by which the budget is formulated and implemented are important and that they influence organizational outcomes. This study assesses effect of budgeting process on organizational effectiveness in the government finance organization of Hadiya zone. The study has a targeted 262 staff employee from 5 selected woredas. Those woredas were selected purposely from the 12 woreds due to their establishments' priorities. The study employed a descriptive survey research design targeting the staff in the government finance organization of Hadiya zone. A sample of 150 staff members was selected by using mulit-stage sampling system and, which were stratified and at last, simple random sampling systems were applied in the study. The researcher was mainly employed a structured questionnaire, unstructured interview's and secondary source of data used for triangulation purpose for primary data. Data was analyzed in form of descriptive and multiple linear regression models. Data was analyzed using Statistical computer software Package. Results: The findings were presented in form of tables, figures and discussions there. The study established that effect of budgeting process capacity had a strong positive significant relationship with the organizational effectiveness.Conclusion: Result indicates that Governmental Finance Organization should enhance its organizational capacity in the budget process in order to improve its organizational effectiveness.
\end{abstract}

Keywords: Budgeting process, Hadiya Zone Government Finance, Organizational effectiveness.

DOI: $10.7176 / \mathrm{RJFA} / 11-5-04$

Publication date:March $31^{\text {st }} 2020$

\section{Background}

A properly managed program budget process can promote sustainable effectiveness in many government organizations .Commonly; organizations operate using several resources including financial, human, capital and others financial resources also are the key elements in achieving organizational objectives and goals. Thus, to achieve that organizational objective the budgeting process must be organized efficiently and followed effective budget plan (Assey, 2014).

(Kariuk.J, 2012)focused on the budget implementation factors that influence effectiveness of public institutions in Kenya though she focused on only one state corporation the report gave an overview of the institution and the budget process it has adopted but only challenges of budget implementation in public institutions was considered.

Budgeting is a process of planning the organizational operations for its effectiveness. It is also as a management tool helps to organize and formulize management's planning process for organizational goal achievement and financial tool is useful for both evaluation and control of organizations for the planning of future activities. Those all are why an efficient programmed budgetary systems has a positive effect on the ability of the budgeting process to anticipate and respond with expressed measures to opportunities and pressures from the environment in which the organizations operates(Kariuki, 2010)

Agreeing to (Isaboke, 2014)government prepares reform of public policy to serve as a driving force through which mission could be achieved. Effectively prepared budgeting process can be measured in terms of achievement of its goal but, budget achievement was far from reality and the gap between budget and organizational success are so wide range and kept on point for many years ago.

Similarly, the effect of budgeting process on organizational effectiveness less studied in the local government organization in Ethiopia (Ketema, 2015). So, this study tried to fill the area gap of previous studies by examining the effect of budgeting process on organizational effectiveness in Hadiya zone selected government finance organization. 


\section{Methods}

\subsection{Target Population and Sampling Frame}

The study has a target 262 staff employee from 5 selected woredas government sectors in Hadiya zone .The five woreds government finance sectors were selected purposely from the 12 woredas.

According to(Orodho., 2009), a sampling frame is a set of information used to identify a sample population for statistical treatment and also he noted that, the sampling frame must be representative of the population. Therefore; the sample frame of the study was the targeted Population of the study which was 262 employees of all the staffs of the five woredas government finance sectors. The sampling frame was picked from the Human Resource Manager of Hadiya zone government finance organization.

\subsection{Sample size}

There are 12 total number of public finance sectors in Hadiya zone .From those 5 public finance sectors were selected purposely due to their establishments' priorities and more experienced staff members, full manpower that helps to identify problems effectively and stratifying all staff members in their departments in case of homogeneity of their job characteristics and finally, the researcher makes random sampling method. On the other hand determined the sample size and95\%conifdinece level the researcher used (Kothari \& Carilason., 2012) formula.

$: n=Z^{2} \cdot p \cdot q \cdot \frac{N}{\mathrm{e}^{2}(N-1)+Z^{2} \cdot P \cdot q}$ Where: $\mathrm{N}=$ size of population $\mathrm{n}=$ size of sample $\mathrm{p}=$ sample proportion of successes $\mathrm{q}$ $=1-\mathrm{p} \mathrm{z}=$ the value of the standard variety at a given confidence level $\mathrm{e}=$ acceptable error (the precision) $\mathrm{q}=$ sample proportion of faller. $\mathrm{e}=5 \%, \mathrm{p}=.65, \mathrm{q}=1-\mathrm{p}=.35, \mathrm{z}=1.96 \mathrm{n}=\mathrm{z}^{2} \cdot \mathrm{p} . \mathrm{q} . \mathrm{N} / \mathrm{e}^{2}(\mathrm{~N}-1)+\mathrm{z}^{2} \cdot \mathrm{p} \cdot \mathrm{qN}=262$ ， $\mathrm{n}=(1.96)(1.96)(.65)(.35)(262) /(.05)(.05)(262-1)+(1.96) 91.96)(.65)(.35)=150$

\subsection{Sampling Technique and procedure}

According to (Nairobi \& AOrodho., 2009) (for this research, a multi-stage sampling technique was employed to draw sample employee for the study. The first stage 5 Woredas were purposively selected out of 12 .

Second stage, each woreda staff members encompasses into 5 sub-stratums according to their homogeneity or departments and the employees selected based on proportionately simple random selection sampling technique was used applied to get more relevant information.

\subsection{Data Analysis methods and techniques}

The process of data analysis involved data cleanup and explanation, after that the data was coded and checked for any errors and omissions (Kothari \& Carilason., 2012).Data analysis was applied to examining, categorizing, tabulating, testing or otherwise recombining qualitative evidence to address the research questions. Data was analyzed by using multiple linear regression models on computer software package

\subsection{Model Specification}

The characteristics of model and the proposed variables in this study have been evaluated for the fulfillment of the classical assumption, according to(Ponsian, 2014)Ordinary Least Squares (OLS) regression model was used: $\mathrm{OE}=\beta 0+\beta 1(\mathrm{BPr})+\beta 2(\mathrm{BPt})+\beta 3(\mathrm{PBI})+\beta 4(\mathrm{BGC})+\beta 5(\mathrm{BCo})+\beta 6(\mathrm{TRB})+\varepsilon .$.

The regression model presented the dependent variable (organizational effectiveness) and independent variables on the budgeting process were expressed as in the equation below: $O E=$ organization effectiveness, $\beta 0=$ intercept

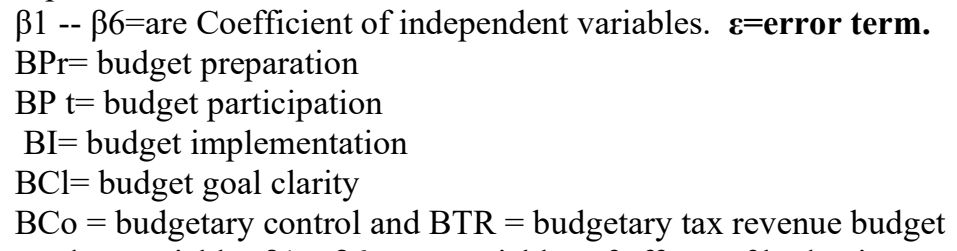

The independent variables $\beta 1-\beta 6$ were variables of effects of budgeting process on organizational effectiveness for this study which was measured through various questioners by asking the respondents about the questionnaires. The regression was employed to test the effect of budgeting process on organizational effectiveness. A five point likert scale was used to interpret the level of ranking.

\section{Results and Discussions}

\subsection{Descriptive Statistics}

The results in the above Table1 on the field of study of an employee researched on was that $38 \%$ have been in existence for $38 \%$ accounting, $42.7 \%$ were management, $12.7 \%$ economics were while $2.7 \%$ of the employee were for others . The results of the figure show that majority of the employee had been in operation on average about $42.7 \%$ were for the field of management , $38 \%$ accounting and others field employee were with the combination 
of fields of specialization are making an effective budgeting process and also realize the objectives of the organization.

Table 1 : field of study of respondent

\begin{tabular}{|l|l|l|l|l|l|}
\hline \multicolumn{2}{|c|}{} & Frequency & Percent & Valid Percent & Cumulative Percent \\
\hline \multirow{3}{*}{ Valid } & Accounting & 57 & 38.0 & 39.6 & 39.6 \\
\cline { 2 - 6 } & Management & 64 & 42.7 & 44.4 & 84.0 \\
\cline { 2 - 6 } & Economics & 19 & 12.7 & 13.2 & 97.2 \\
\cline { 2 - 6 } & Other & 4 & 2.7 & 2.8 & 100.0 \\
\cline { 2 - 6 } & Total & 144 & 96.0 & 100.0 & \\
\hline Missing & System & 6 & 4.0 & & \\
\hline Total & 150 & 100.0 & & \\
\hline
\end{tabular}

Source: Own computation, 2019

The results in table 2 showed that the level education of the employee were $12 \%$ have been in existence certificate, $42 \%$ was Diploma while $42 \%$ of the employee was Degree. The results mean that majority of the equal amount percentage of the employee had been in operation on average about $42 \%$ were Diploma and Degree holders had been to establish an effective budgeting process and skilled people availability in the sector, that make good task force and also realize the objectives of organizational effectiveness.

Table 2: level education of employee

\begin{tabular}{|llllll|}
\hline \multirow{5}{*}{ Valid } & & & & & \\
& Certificate. & 18 & Percent & Valid Percent & Cumulative Percent \\
\cline { 2 - 6 } & Diploma & 63 & 12.0 & 12.5 & 12.5 \\
\cline { 2 - 6 } & Degree & 63 & 42.0 & 43.8 & 56.3 \\
\cline { 2 - 6 } & Total & 144 & 42.0 & 43.8 & 100.0 \\
\hline Missing & System & 6 & 96.0 & 100.0 & \\
\hline Total & & 150 & 100.0 & & \\
\hline
\end{tabular}

Source: Own computation, 2019

The results in Table 3 , experience year of the employee researched on was that $1.3 \%$ have been in existence for one years while $4 \%$ of the employee was two years, $34 \%$ was three year and very high amount of them means $85 \%$ employees were above four year experience. The results mean that majority of the experience an employee had been in operation in Hadiya zone government finance organization on average about $85 \%$ and this can be taken to imply that the organization have long enough an employee experience had been to establish an effective budgeting process and also realize the objectives of organizational effectiveness

Table 3: ES (Year of Experience)

\begin{tabular}{|c|l|l|l|l|l|}
\hline \multicolumn{2}{|l|}{ Experience Year } & Frequency & Percent & $\begin{array}{l}\text { Valid } \\
\text { Percent }\end{array}$ & $\begin{array}{l}\text { Cumulative } \\
\text { Percent }\end{array}$ \\
\hline \multirow{3}{*}{ Valid } & 1 & & & 1.4 & 1.4 \\
\cline { 2 - 6 } & 2 & 2 & 1.3 & 4.2 & 5.6 \\
\cline { 2 - 6 } & 3 & 6 & 4.0 & 35.4 & 41.0 \\
\cline { 2 - 6 } & Above 4 & 51 & 34.0 & 59.0 & 100.0 \\
\cline { 2 - 6 } & Total & 85 & 56.7 & 100.0 & \\
\hline Missing & System & 144 & 96.0 & & \\
\hline Total & 150 & 100.0 & & \\
\hline
\end{tabular}

Source: Own computation,2019

\subsection{Regression Analysis}

\subsubsection{Assessment of Normality Test}

In the Normal Probability important diagnostic test conducted in this paper is the normality assumption i.e. the errors should be normally distributed. .According to (Fidell, 2001 ) a full description of how to interpret a residuals plot and how to assess the impact that violations may have on the analysis. The presence of outliers can also be detected from the Scatter plot.(Fidell, 2001 ) define outliers as cases that have a standardized residual (as displayed in the scatter plot) of more than 3.3 or less than -3.3.In order to test the normality of data, tests of normality were used and conducted on SPSS 20, it shows that the distribution of the sample do not significantly different from a normal distribution. Accordingly, the result of test showed in figure 4 and 5 below and that all variables were found to be normal and the presence of normality was accepted at $p>0.05$ 


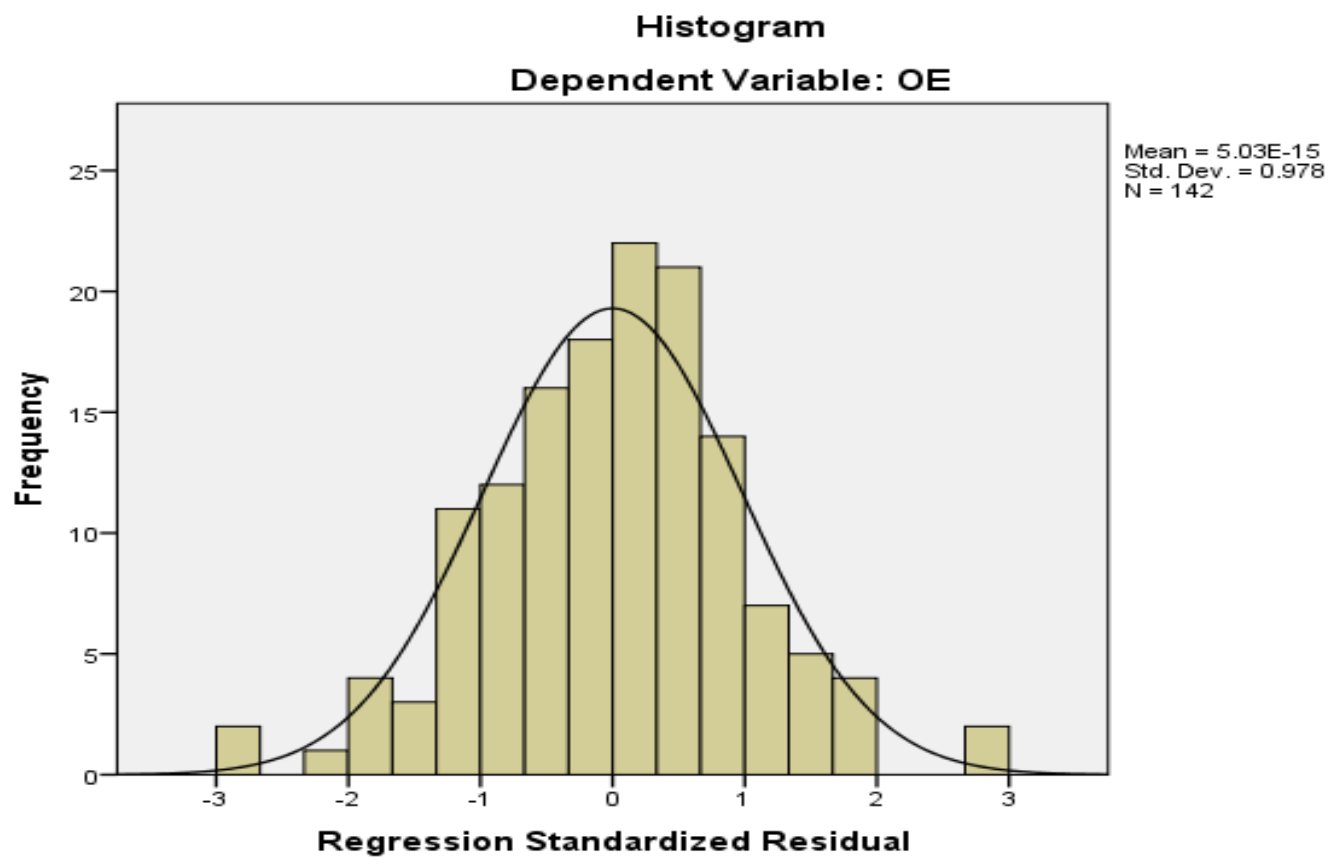

Source: Own computation, 2019

\subsubsection{Strength of independent variables in the Regression model}

Analysis in table 4 in the below shows that the coefficient of determination (the percentage variation in the dependent variable being explained by the changes in the independent variables) R2 equals 0.561 , that was, $\mathrm{BPr}$, $\mathrm{BPt}, \mathrm{BI}$, and BGcl explains $56.1 \%$ of observed change on organizational effectiveness as measured by those variables. The P- value of 0.000 (Less than 0.05 ) implies that the regression model was significant at the $95 \%$ significance level.

Table 4 : Independent variables Coefficient

\begin{tabular}{|c|c|c|c|c|c|c|c|c|c|c|}
\hline \multirow{2}{*}{\multicolumn{2}{|c|}{ Model }} & \multicolumn{2}{|c|}{$\begin{array}{l}\text { Unstandardized } \\
\text { Coefficients }\end{array}$} & \multirow{2}{*}{$\begin{array}{l}\text { Standardized } \\
\text { Coefficients } \\
\text { Beta }\end{array}$} & \multirow[t]{2}{*}{$\mathrm{T}$} & \multirow[t]{2}{*}{ Sig. } & \multicolumn{2}{|c|}{$\begin{array}{l}95.0 \% \\
\text { Confidence } \\
\text { Interval for B }\end{array}$} & \multicolumn{2}{|c|}{$\begin{array}{l}\text { Collinearity } \\
\text { Statistics }\end{array}$} \\
\hline & & B & $\begin{array}{l}\text { Std. } \\
\text { Error }\end{array}$ & & & & $\begin{array}{l}\text { Lower } \\
\text { Bound }\end{array}$ & $\begin{array}{l}\text { Upper } \\
\text { Bound }\end{array}$ & Tolerance & VIF \\
\hline \multirow[t]{7}{*}{1} & (Constant) & .305 & .316 & & .967 & .335 & -.319 & .929 & & \\
\hline & $\mathrm{BPr}$ & .255 & .109 & .278 & 2.343 & .021 & .040 & .470 & .230 & 4.342 \\
\hline & $\mathrm{BPt}$ & .250 & .105 & .254 & 2.385 & .018 & .043 & .457 & .287 & 3.479 \\
\hline & BI & .214 & .085 & .236 & 2.511 & .013 & .045 & .382 & .367 & 2.725 \\
\hline & $\mathrm{BCO}$ & .048 & .054 & .054 & .882 & .379 & -.059 & .155 & .871 & 1.148 \\
\hline & $\mathrm{BCl}$ & .094 & .049 & .122 & 1.901 & .059 & -.004 & .191 & .795 & 1.258 \\
\hline & BTR & .018 & .057 & .018 & .311 & .756 & -.096 & .131 & .949 & 1.054 \\
\hline
\end{tabular}

Source: Own computation,2019

$\mathrm{Y}=\hat{\beta}_{0}+\hat{\beta}_{1} X_{1}+\hat{\beta}_{2} X_{2}+\hat{\beta}_{3} X_{3}+\hat{\beta}_{4} X_{4}+\hat{\beta}_{5} X_{5}+\hat{\beta}_{6} X_{6}+--------+\varepsilon$

$\mathrm{Y}=.305+\hat{\beta}_{1}(B P r)+\hat{\beta}_{2}(B P t)+\hat{\beta}_{3}(B I)+\hat{\beta}_{4}(B C O)+\hat{\beta}_{5}(B G c l)+\hat{\beta}_{6}(B T R)$

$\mathrm{Y}=.305+.255(B P r)+.250(B P t)+.214(B I)+.048(B C O)+.094(B G c l)+.018(B T R)$

The coefficient of intercept constant has a value (0.305)was at $95 \%$ confidence level that was applied in the analysis. The coefficient of budget preparation was 0.255 and was significant at $5 \%$ significance level. This means that a unit increase in the budget preparation will increase the Organization effectiveness of the firm by 0.255 units. The coefficient of budget participation was 0.250 and was significant at $5 \%$ significance level. This means that a unit increase in the budget participation will increase the Organization effectiveness of the firm by 0.250 units.

The coefficient for budget implementation is 0.214 , So for every unit increase in budget implementation, 0.214 unit increase in organization effectiveness is predicted, holding all other variables constant. The coefficient for budget implementation (0.214) is significantly different from 0 because its $p$-value is 0.013 , which is smaller than 0.05 .The coefficient of budgetary goal clarity is 0.094 and is significant at $5 \%$ significance level. This means 
that a unit increases in the budgetary goal clarity will increase the Organization effectiveness of the firm by 0.094 units. Further, the findings indicated that most respondents strongly agreed that budget preparation time call letters do not circulate for all sectors on time and Budgets are not planned according to the Organizational goal Objectives and majority of the participants do not satisfied with budget preparation because of they do not participate in their department/ organization budget Preparing and they do not participate when their department expenditure budgets to implementation and also there is less communication between top and lower level managements when the organizational budget planning.

As result by most respondents were said that budget preparation and budgetary participation affects to a very great extent on organizational effectiveness in Hadiya zone government finance sectors. The study further revealed that most respondents strongly agreed that they do not know clearly about expenditure budget implementation in their office, they have not budgetary goal clarity in their department/office and also the prepared budget goals are not stated specifically and clearly in their office. It was also concluded that organizational effectiveness was measured by organizational goal achievement and its independent variables and it was influenced by Budget Preparation $(p=0.021)$, Budgetary participation $(p=0.018)$ Budgetary goal clarity $(p=0.059)$. The independent variables in the regression model with positive coefficient revealed that there was a direct relationship with the dependent variable.

Budget preparation: A well designed organizational budget preparation is expected to contribute positively to the organizational goal achievement(Ponsian1 \& Chrispina1, 2014)). Moreover, this study examined that good budget preparation was expected to have better organizational success. In the table 4, the significance was found to be 0.000 . This can be interpreted as the relationship between budget preparation and organization effectiveness was significant. The coefficient for budget preparation in the simple linear regression was ( 0.255$)$. So for every unit increase in budget preparation, a 0.255 unit increase in organization effectiveness is predicted, holding all other variables constant. The coefficient for budget preparation $(0.255)$ is significantly different from 0 because its p-value is 0.021 , which is smaller than 0.05 . Further, the findings indicated that most respondents strongly agreed that budget preparation time call letters did not circulate for all sectors on time and Budgets did not planned according to the Organizational goal Objectives and majority of the participants was not satisfied with budget preparation because of they did not participate in their department/ organization budget Preparing and they did not participate when their department expenditure budgets have implementing and also there was less communication between top and lower level managements when the organizational budget planning. As result by most respondents were said that budget preparation was affects to a very great extent on organizational effectiveness in Hadiya zone government finance sectors.

Budgetary participation:.(Mwaura, 2010)Conclude that budgetary participation affects capital of organization and return on asset in a great extent in public finance. First, according to regression analysis results of this study suggested that the effects of budget participation were positive and significant. Secondly this study was found out that the organizational performance scores were increase when the relations score between budget participation and organizational assurance increase. Therefore, in this study it is expected that it is positively related to organizational effectiveness. In the regression analysis table 4 , the significance was found to be 0.000 . This can be interpreted as the relationship between budget participation and organization effectiveness is significant. The coefficient for budget participation (.250) is significantly different from 0 because its p-value is (0.018), which is smaller than 0.05 . This means that a unit increase in the budget participation will increase the Organization effectiveness of the firm by 0.250 units

Budgetary goal clarity:(May \& Yang, 1980)shows the delivery of small and medium-sized firms among the different levels of budget goal clarity. Observing the descriptive results can get some facts: Firstly, more firms at a high level of budget goal clarity report more frequently achieving budget goal, compared to low level of budget goal clarity on the firms. Finally, the result concludes that the more budget goal clarity will reach to the more organizational goal achievement. So, as above researcher this paper expected that is positively related to organizational effectiveness. In the table 4, the significance was found to be 0.059 .

(Hirst \& Yuen, 2004)has long stressed the beneficial effect of budget goals clarity on promoting effectiveness of an organization. A large group of previous studies Yuen, 2004 analyze the characteristics of the budget goal from two aspects and show their potential link with organizational effectiveness.

"Goal clarity refers to the extent to which budget goals are stated specifically and clearly, and are understood by those who are responsible for meeting them" (Yuen,2004). Researcher would believe that managers working with unclear goals are faced with higher uncertainty in relations to goal achievement, while clear goals reduce uncertainties in the budgeting process and which, in turn, will improve performance of organizational. Moreover, realizing the motivational role of budget goals, previous studies(Hirst \& Yuen, 2004) also state that clear goals promote the performance of employees by urging them to do the best they can whereas lack of clarity leads to confusion, tension, and dissatisfaction among employees.

The coefficient for Budgetary Goal Clarity (0.094) is significantly different from 0 because its p-value is, 0.059 which is smaller than 0.05 . The coefficient of budgetary goal clarity is 0.094 and is significant at $5 \%$ 
significance level. This means that a unit increases in the budgetary goal clarity will increase the Organization effectiveness of the firm by 0.059 units by holding all other variables constant. The study further revealed that most respondents strongly agreed that they do not know clearly about expenditure budget implementation in their office, they have not budgetary goal clarity in their department/office and also the prepared budget goals are not stated specifically and clearly in their office. It was also concluded that organizational effectiveness was measured by organizational goal achievement and which can be interpreted as the relationship between Budgetary Goal Clarity and organization effectiveness is significant. This result showed that all employees should be involved in Budgetary Goal Clarity will make the effective organization.

Budgetary Implementation:: A well budget implemented organization is expected to contribute positively to the creation of a firms' value and high presentation reflects organization effectiveness and efficiency in making use of firm's resources and this in turn contributes to the country's economy at large(Nyageng'o, 2014). This study projected that effective program budget implementation was positively related to organizational effectiveness. In the table 4 , the significance was found to be 0.013 and which can be interpreted as the relationship between budget implementation and organization effectiveness was significant. This result shows that all the employers must be involved in all budget implementation to make the effective organization.

The coefficient for budget implementation (.214) is significantly different from 0 because its p-value is 0.000 , which is smaller than 0.05 . So for every unit increase in budget implementation, .214 unit increases in organization effectiveness is predicted, holding all other variables constant. The coefficient for budget implementation $(0.214)$ is significantly different from 0 because its p-value is 0.013 , which is smaller than 0.05 .Finally, these all the above the regression results were the same to primary data from quaternaries, interviews and qualitatively from secondary data implied results.

Generally, according to the secondary and primary data responses or from questionnaires, interviews and from secondary data on different financial report information's concluded that, the organization faces budget shortage during the budget year, the employees did not know differences between budget plan and organizational goal in clear way, the expenditure budget did not consistent with its organizational goal achievement, the employees did not know in clear way about expenditure budget implementation in the office and they did not involve in their department budget implementing for organizational effectiveness. Those all results were the same to regression analyses and have high effect on organizational effectiveness.

\section{Conclusion}

According to the regression output all these predictors were positively contributed to the organizational goal achievement in Hadiya Zone public finance sector. Moreover, the budgetary preparation and budgetary participation, budgetary goals clarity, budgetary implementation were the major determinants of in the public finance sector. However, budgetary control and budgetary tax revenue were not significantly important for the of public finance sectors.

This study finds that the composite measure of the budgetary preparation and budgetary participation budgetary implementation budgetary goal clarity budgetary control and BTR for $56.10 \%(\mathrm{R} 2=0.561)$ variance for the OE in identifying activities and added contributions to the public finance sector. That means, the impact of these six independent variables contributed for thedependentvariableOEwere $56.10 \%$, and the remaining $43.90 \%$ were other variables that are not included in this study.

The findings of the study concluded that the magnitude of coefficients of the independent variables denoted the strength of the influence that they have on the dependent variable .The results indicated that organizational effectiveness was measured by its independent variables which are strongly influenced by Budget Preparation(.255)Budgetary participation ( 0.250) and budgetary implementation( 0.214) Budgetary goal clarity( 0.094) respectively. The findings of the study was relevant due, budgetary Preparation budgetary participation budgetary implementation and budgetary goal clarity, are critical inputs in budgeting process for organizational effectiveness.

From the research findings and the answers to the research questions, some conclusions can be, made about the study. Adoption of effective budgeting process has an effect in the success of the plans set as well as for organizational goal achievement. It is also important that a organizational should explore the need to adopt on budgetary goals clarity, budgetary participation and budget preparation in budgetary process.

Such adoption will increase the success of the organizational of that sector. An organization should put in place budget practices which assist in accomplishing a principle and element of the budget process. A budgeting process typically has multiple practices associated with it. The budget practices must be clearly related to activities identified in the budget process. The success in implementing the principles, elements, and practices should not be measured by how rapidly they are incorporated into the budget process but, successful implementation is likely to take a number of years in order to build the necessary level of understanding among all participants. The findings indicates that budgetary procedures are an important aspect of an organization's budgetary system because they promote more positive attitudes and behaviors on the part of managers, supervisors and employers with budget 
responsibility, which ultimately will enable the organization to better accomplish its goals and objectives.

The multiple regression analysis results indicated that there was a strong and statistically significant relationship between budgeting processes and organizational effectiveness. Therefore, this study concludes that budgeting processes have a strong positive effect on organizational effectiveness in the public finance organization in Hadiya zone.

\section{Recommendations}

After watching the research findings and achieved results with regard to the main objective of this study to identify the major effects of budgeting process on organization effectiveness in the public finance sector and also to prove the hypotheses, the researcher provides the following recommendations to the public finance sector in Hadiya zone SNNPR, Ethiopia.

$>$ The finding of this research proved that the budgetary preparation and budgetary participation, budgetary implementation and budgetary goal clarity were statistically significant and positively related with the OE in the public finance sector. Thus, the public finance sector should budgetary participation more for the finance sector employee by facilitating the works, and should budgetary goal clarity will implemented when in preparation time and other.

$>$ The organization should participate its employees at a particular preferred level, in order to benefit from the efficiency and the success of the organization. The Participation encourages an employee to work hard in relation to the given budget, when employees work hard it means the organization can easily achieve its goals.

$>$ Government finance organizations need to identify with their stakeholders and involve them throughout the budgeting process to ensure chances of success when budget planning time and make implantation budget consistent with its plan.

$>$ It concluded that the interactions specially use budgetary goal clarity, budgetary participation and budget Preparation of the four factors are inputs in budgeting process for organizational effectiveness, and hence Hadiya zone government finance sectors should adopt strategies to enhance these to four areas.

\section{Reference}

Assey, D. (2014). Doreen do effectiveness of budgeting process in achieving organizational goals: A case of Temesa.

Isaboke, E. M. (2014). Assessment of budgeting process on financial performance of country government of Nakuru, KENYA ACCA. financial GSL , 245-354.

Kariuk.J. (2012). Budgeting: A fundamental management tool. KasnebNewsline Volume 1, p.4).

Kariuki. (2010). Budgeting: A fundamental management tool. . American: merican politicalscience association.

Ketema. (2015). Assessment of Budget Preparation and Utilization:.

Kothari, \& Carilason. (2012). Research methodology: Methods and techniques, 2nd edition, ) Ltd, New Delhi, India. New International $(\mathrm{P}$.

Nairobi, \& AOrodho. (2009). O Elements of Education and Social Science Research Methods. Nairobi; Kenya, KanezjaPublishers.Hospitality Industry. Journal of Finance and Economics, 1(3) , 39-50.

Orodho. (2009). Elements of Education and Social Science Research Methods. Nairobi; Kenya, KanezjaPublishers.Hospitality Industry. Journal of Finance and Economics, 1(3), 39-50. Nairobi: KanezjaPublishers.

Ponsian. (2014). The effect of working capital management on profitabilitya case study of City Council. 